\title{
Utilizing Educational Technologies to Optimize Student and Teacher Learning at Dharma Laksana Mataram Orphanage
}

\author{
Paula Dewanti ${ }^{1 *}$ \\ ${ }^{1}$ Department of Information Systems, Faculty of Informatics and Computers \\ ITB STIKOM Bali, Denpasar, Indonesia \\ paula_dewanti@stikom-bali.ac.id \\ Ni Nyoman Supuwiningsih ${ }^{2}$, Desak Putu Saridewi ${ }^{3}$ \\ ${ }^{2}$ Computer System, ITB STIKOM Bali, Denpasar, Indonesia \\ ${ }^{3}$ Early Childhood Education, IAHN Gde Pudja Mataram, Mataram, Indonesia \\ supuwiningsih@stikom-bali.ac.id, saridewi@iahn-gdepudja.ac.id
}

(Received May 02, 2021, accepted June 18, 2021)

\begin{abstract}
Educational technology is the study and practice of using technology to facilitate and enhance learning performance. During the Covid-19 pandemic, digital learning and the use of information technology were one of the solutions to minimize the risk of Covid-19, according to the government's health protocol. As a Non-Governmental Organization (NGO), the Dharma Laksana Orphanage receives computer set donations from their funders. Based on preliminary reviews, the use of these computer devices is not optimal, both for students and teachers. The inability to optimize the use of computer devices seems to have an impact on the effectiveness of learning approaches by utilizing information technology. This Community Service was performed using the Service Learning methodology and was designed to assist in the development of human resources related to learning methods and media used during the Covid-19 pandemic. During this activity, Edmodo, the leading social learning platform, was successfully introduced. Blended Learning with Google Apps is also covered. It increased both student and teacher awareness of digital learning, as well as teacher competence in creating interactive learning media, by introducing a variety of educational platforms.
\end{abstract}

Keywords: community engagement; educational technology; learning enhancement 


\section{Introduction}

During the Covid-19 pandemic, digital learning and the use of information technology were one of the solutions to minimize the risk of Covid-19, according to the government's health protocol. As a Non-Governmental Organization (NGO), the Dharma Laksana Orphanage receives computer set donations from their funders. The Dharma Laksana Mataram Orphanage's main challenge is the limited ability to optimally use donated computer devices, which is caused by a lack of digital learning skills between teachers and orphanage students. Using Educational Technologies, the team will use a live-face-to-face communication platform, which can be considered a new norm of Blended Learning, as well a Forum Group Discussion (FGD) to increase both student and teacher awareness of digital learning, as well as teacher competence in creating interactive learning media, by introducing a variety of educational platforms.

\section{Methods}

\section{Implementation Method of Community Service}

This Community Service conducted using the Service Learning methodology. Service Learning is a methodology that is based on the needs, problems, or real challenges that can be found in both the local and global context. Service Learning begins with an analysis and review of reality in order to determine which intervention the students can carry out to improve the identified deficiencies (Selmo, 2015). Exposure, practice, and discussion were used to provide Digital Learning training for students and teachers at Panti Asuhan Dharma Laksana Mataram. The method of exposure is carried out by providing instructions on how to browse, search, download, and use the digital learning application, as well as how to proceed with the program. The next step is to practice on the computer with the previously taught material. Following that, the discussion is continued by allowing time for questions or responses from the participants.

Due to government restrictions on community activities, Pemberlakuan Pembatasan Kegiatan Masyarakat (PPKM) during the Covid-19 pandemic, the training was conducted virtually for the first two meetings of eighty minutes each, using the Zoom application. The training is done through online between the team and its partners through the Zoom application. Since some team members live in Mataram, they are able to present offline at the 
same time. Following the training, participants are given a training module to use as a reference.

The team consists of three experts in the field who are Lecturers from diverse research programs. Aside from the Lecturers, the team also includes three students of different study programs, Computer Systems, Information Systems, and Law, with the objective of collaboration and complementing each expertise.

\section{Implementation of Activities}

This Community Service Implementation Activity took place between February and April in 2021, as shown in Table 1.

Table 1. Implementation schedule

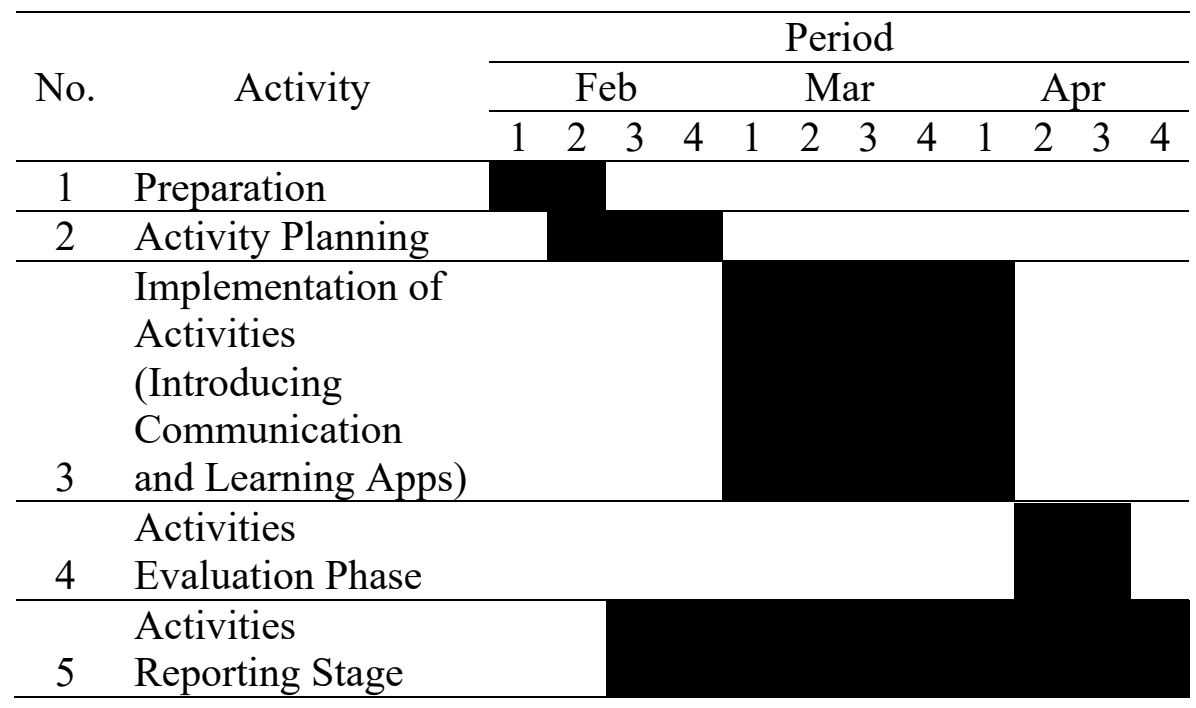

\section{Location}

This Community Service was conducted in collaboration with the Dharma Laksana Mataram Orphanage, which is located 132 kilometers from ITB STIKOM Bali on Jalan Dr. Soejono No.15, Lingkar Selatan, Mataram. The orphanage house, now known as the Lembaga Kesejahteraan Sosial Anak (LKSA), a child social welfare organization, was established with the intention of assisting school-age Hindus from disadvantage families in obtaining a proper education. The orphanage children are accommodated and supported by the foundation, which is funded by benefactors, the community, and the government. Based on Panca Sradha, the Dharma Laksana Mataram Foundation envisions itself as a center for the education and development of quality and competitive Hindu human resources. 
Aside from the Orphanage, the Dharma Laksana Mataram Foundation also oversees Dwijendra Kindergarten (TK), Dwijendra Elementary School (SD), Dwijendra (Jr. High School), and Kertya Wisata High School, each of which are in the same area as the Dharma Laksana Mataram Orphanage. The Dharma Laksana Foundation was established to provide Hindus in West Nusa Tenggara with better access to Hindu-inspired educational services, to increase the provision of educational facilities for Hindus in West Nusa Tenggara from Kindergarten level to High School (SMA/SMK) level, and to improve the provision of facilities for the development of Social Organization for Children and Pesraman, in addition to preparing adequate and safe learning facilities and facilities for students and foster children. Figure 1 to Figure 3 shows the situation analysis of the location.

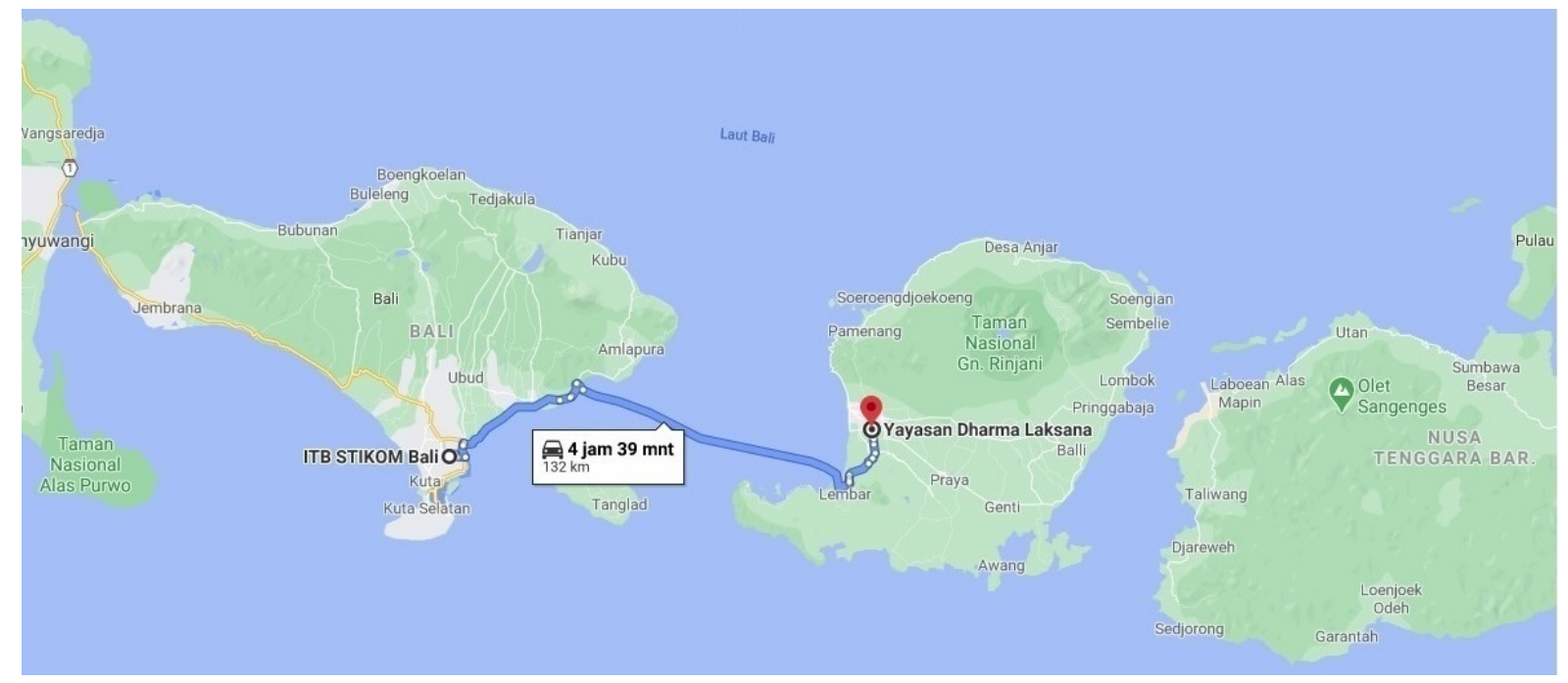

Fig. 1. Location maps (Bali Island Map, 2020)
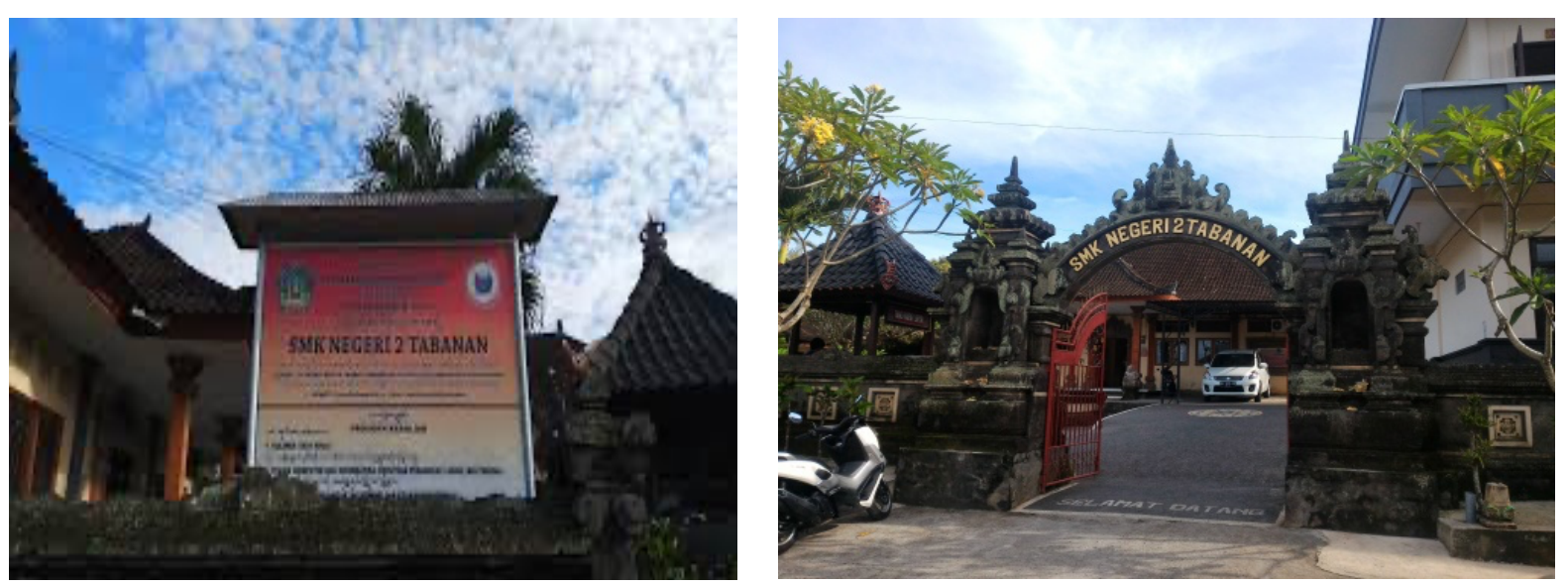

Fig. 2. Location of community service 

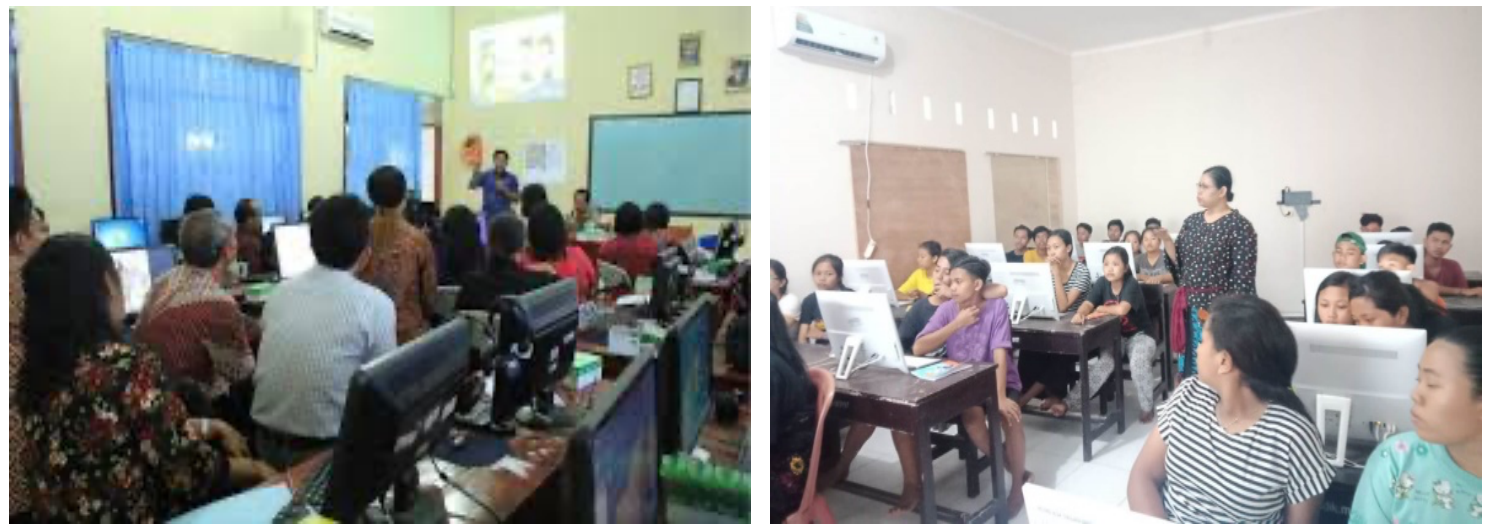

Fig. 3. Learning atmosphere

\section{Results and Discussions}

\section{Results}

The team took an initial approach based on the problems described above to find solutions to the main problems that existed at the Dharma Laksana Mataram Orphanage. The following solutions were prioritized in this Community Service based on the agreement with the Partner.

- Providing Internet data packages to assist the Dharma Laksana Mataram in keeping the learning process going during Community Service.

- Providing technicians to assist with learning at the Dharma Laksana Mataram during Community Service.

- Introducing Zoom video communication apps, which can be used to connect virtually, via the WhatsApp application and the on-site team.

- Provide digital learning training to Dharma Laksana Mataram students and teachers, particularly at the High School level.

- Teachers at Dharma Laksana Mataram are being trained on how to create simple digital learning media in order to provide more appealing learning options to students.

- Provide a multimedia learning module that can be used as a reference for digital learning at Dharma Laksana Mataram, especially at the High School level.

\section{Discussions}

Virtual communication channels were used for 80 percent of Community Service activities during the current Covid-19 pandemic. As a result, introducing the conferencing application is critical to ensuring that the participants are prepared. A team member was also on-site to 
assist with each session. The team also provided technicians to check all computers used at the Dharma Laksana Mataram before Community Service began.

The following topics were covered in three sessions of two hours and forty minutes each.

Zoom Cloud Meeting Application

Zoom is a video-conferencing app. These applications are compatible with a wide variety of mobile devices and desktop computers. In general, this application is used for video and audio conferences, as well as meetings (Singh \& Awasthi, 2020).

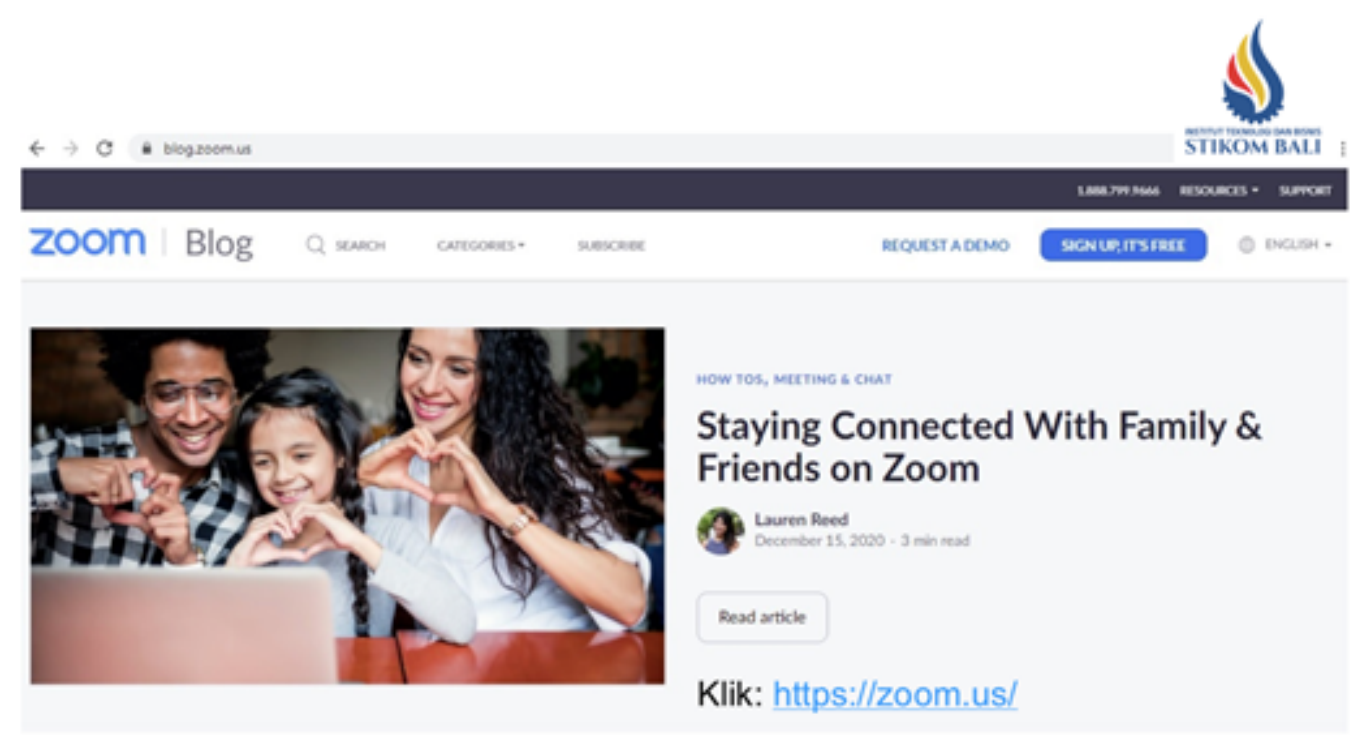

Fig. 4. Zoom learning resources

\section{Edmodo Application}

Edmodo is now widely considered as the most suitable social learning platform (Dewi, 2014). It was developed with the purpose of its use in K-12 classrooms. Edmodo makes it simple for teachers and students in a virtual classroom to connect and collaborate by allowing them to share digital content, hold discussions, and more. Edmodo also integrates with Google Apps for Education, Microsoft OneNote, and Microsoft Office. As a result, users will no longer need to remember multiple passwords or opt out of Edmodo to access Google Drive or collaborate with Google Docs (Dewanti, 2019). 


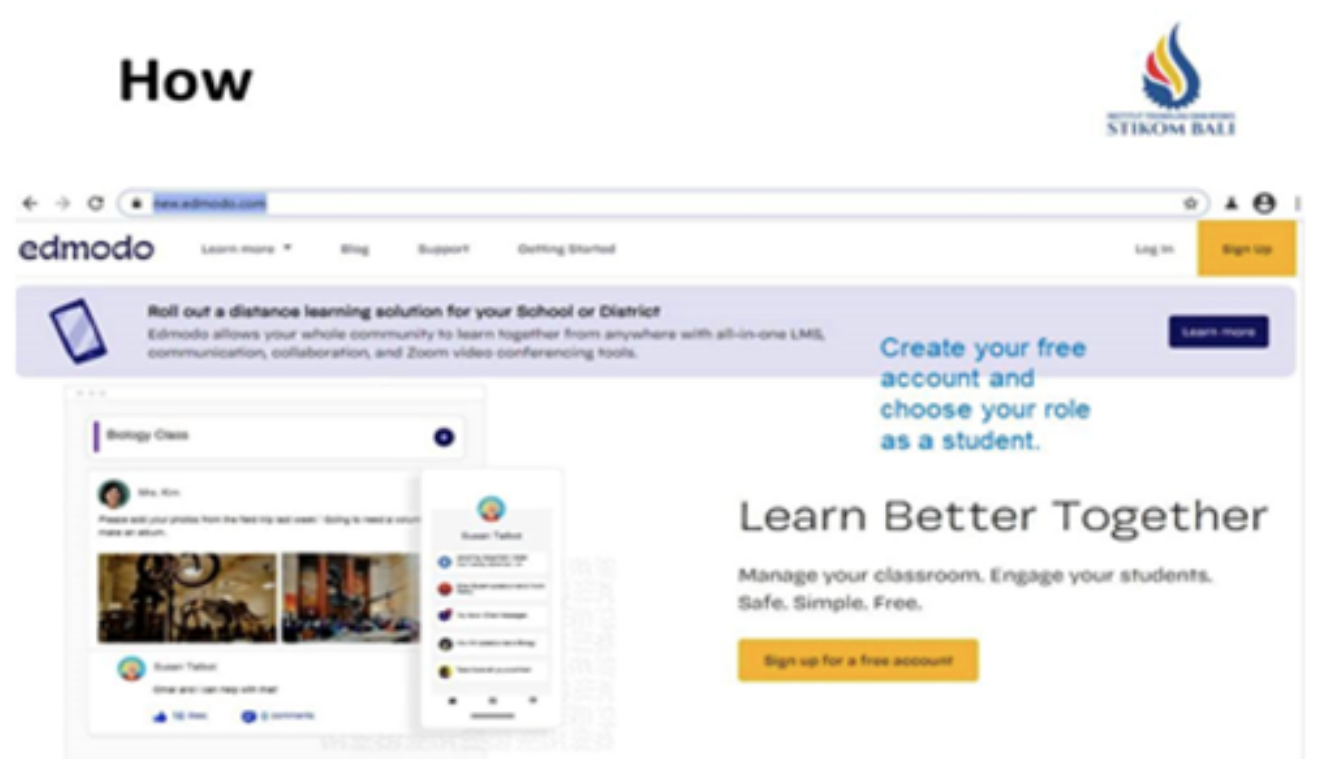

Fig. 5. Edmodo learning resources

PowerPoint

PowerPoint is a Microsoft (MS) Office program used to assist in the creation of presentation material. A variety of presentation-making support features are included in the PowerPoint presentation program (Soni, 2017).

\section{Adobe Captivate}

Adobe Captivate is an example of audio-visual media. Adobe Captivate generates interactive content that is Flash Player compatible and can be easily distributed and accessed online. It includes a number of automatic features that enable users to quickly create complex branching scenarios with feedback options and insert a variety of multimedia files (Dewanti \& Rusli, 2019).

Figures 6 and Figure 7 capture the Community Service implementation at Dharma Laksana Mataram Orphanage. 


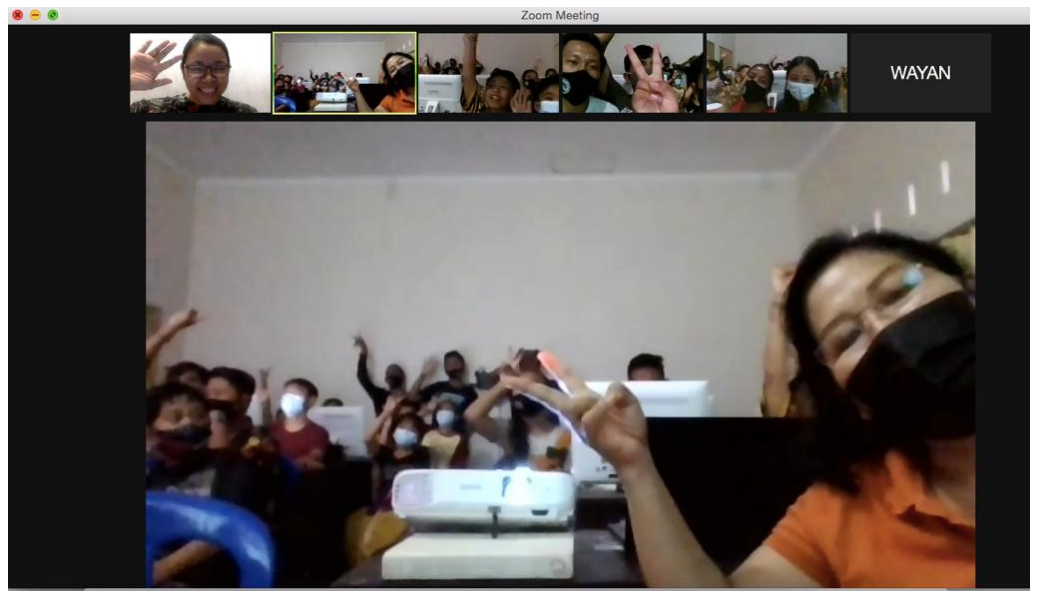

Fig. 6. Day 1 Activity with student

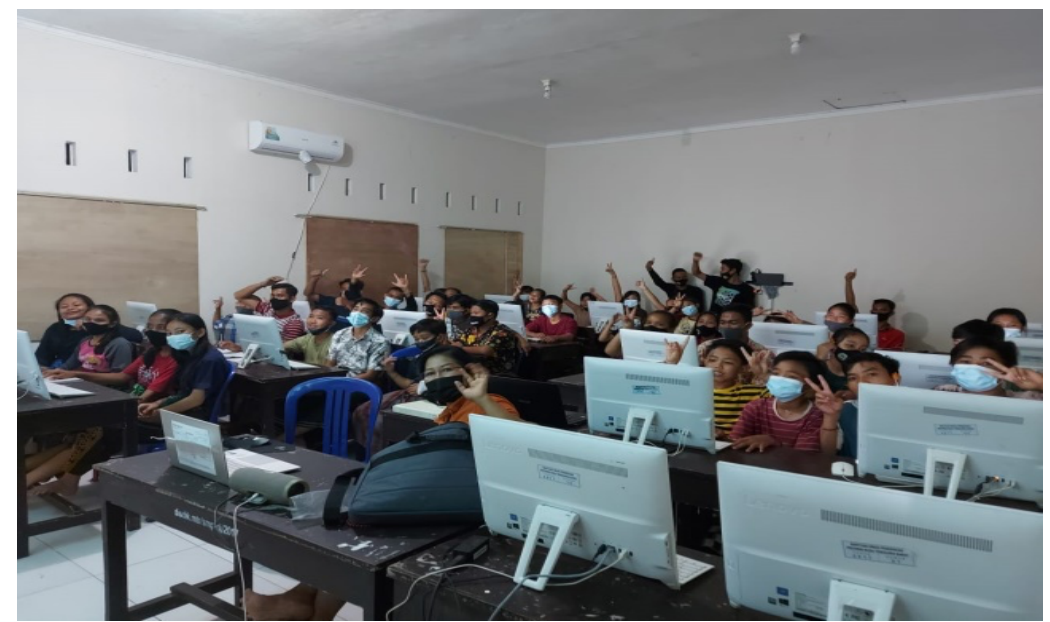

Fig. 7. Onsite team capture

\section{Evaluation}

This training gathered 45 students and 15 teachers from Dharma Laksana Mataram. Since the participants vary in education levels from elementary to high school, the Pretest and Posttest are only used in teacher training sessions. The student learning session was also more teacher-centered, with students receiving one-way information. During the Q\&A session, however, some students were actively asked a few questions. Following the implementation of this Community Service, the team will conduct periodic monitoring every 6 months, or at least once a year, to ensure the effectiveness and sustainability of information technology use in accordance with the advancement of information technology itself.

\section{Conclusion}

The Dharma Laksana Mataram Community Service performed on students and teachers went well, as indicated by the students' and teachers' genuine interest in participating in training 
activities. The program is intended to meet the Chair's expectations by providing relevant information on learning methods and media used during the Covid-19 pandemic. Teachers' knowledge and skills in creating interactive learning media are growing, and students can now use digital learning media to complete tasks assigned to them by their teachers. This can be a small component of traditional classroom-based learning, where teachers record video and text chats, as well as other digitally activated learning activities that are the primary instructional interaction between teachers and students (Firman \& Rahayu, 2020). Traditional classroom methods allow students to spend their entire day learning, but they will also spend more time learning online and independently with guidance from the teacher. In other cases, students can work independently on online materials, projects, and assignments at home or elsewhere, as long as they meet with teachers on a regular basis to review their learning progress, discuss their work, ask questions, and receive assistance with more difficult concepts. Aside from the two cases mentioned above, there are numerous other possibilities (Dewanti, 2019).

Given the recent developments in virus variants and the inability to predict the end of this pandemic period, it is reasonable to continue this Community Service. The Foundation's Chair and teachers enthusiastically welcomed the implementation of this activity and hoped that it could be repeated on a regular basis to assist in the advancement of teacher ability. More implementation, with a focus on Student Engagement and Student Experience, is expected to provide further value and best practice for digital learning implementation during the current Covid-19 pandemic period.

\section{Acknowledgements}

This Community Service was supported by Ministry of Research and Technology/National Research and Innovation Organization (Kemenristek Dikti/BRIN), as well the Institute of Technology and Business (ITB) STIKOM Bali under the 2021 Community Service Program. The team would also like to express gratitude to the students and teachers at Dharma Laksana Mataram for their cooperation and enthusiasm. This Community Service activity would not have been completed as planned without the participants' cooperation, presence, and enthusiasm. Last but not least, recognition goes to the students who took part in this Community Service, Hedi Geger Lino, Kadek Vishnu Vedamurthi, and Anggara Dwi Setiawan, for their dedication to completing their tasks. 


\section{References}

Bali Island Map. 2020. Map Pulau Bali. Bali Citra Satelit. https://www.maps.google.com (Accessed on 15 October 2020).

Dewanti, P., \& Rusli, M. (2019). Implementing Adobe Captivate in Designing E-Learning's Digital Content. International Journal of Computer Applications, 975, 8887. https://doi.org/ 10.5120/ijca2019919552

Dewanti, P. (2019). Optimalisasi Digital Native di Era Industri 4.0. Teknomatika, 9(1). http://ojs.palcomtech.ac.id/index.php/teknomatika/article/view/159

Dewi, F. (2014). Edmodo: A social learning platform for blended learning class in higher education. Research in Education Technology: Pedagogy and Technology Journal, 11(2), 1-11.

Firman, F., \& Rahayu, S. (2020). Pembelajaran Online di Tengah Pandemi Covid19. Indonesian Journal of Educational Science (IJES), 2(2), 81-89.

Selmo, L. (2015). The narrative approach in service-learning methodology: A case study. The International Journal of Research on Service-Learning and Community Engagement, 3(1).

Singh, R., \& Awasthi, S. (2020). Updated Comparative Analysis on Video Conferencing Platforms-Zoom, Google Meet, Microsoft Teams, WebEx Teams and GoToMeetings. EasyChair Preprint no. 4026.

Soni, k. (2017). An Extensible Virtual Assistant for the PowerPoint Presentation Tool. 